\title{
Pengaruh Pemberian Mikrokapsul Minyak Ikan dalam Ransum Puyuh terhadap Performa Produksi
}

\author{
The effect of feeding fish oil microcapsules in laying quails hens \\ on quail performances
}

\author{
Sestilawarti ${ }^{1}$, Mirzah $^{2}$ dan Montesqrit ${ }^{2}$ \\ ${ }^{1}$ Fakultas Peternakan Universitas Jambi \\ Jalan raya jambi Ma bulian KM 15 Mendalo Darat Jambi \\ ${ }^{2}$ Fakultas Peternakan Universitas Andalas \\ Kampus Unand Limau Manis Padang \\ email : sestilawarti@yahoo.com
}

(Diterima: 23 November 2012; Disetujui: 29 Januari 2013)

\begin{abstract}
An experiment was conducted to determine the effect of feeding fish oil microcapsule on quail performances. 200 quail layers were randomly allocated into 20 pens. A randomized completely design was used in this study with $0,2 \%, 4 \%$ and $6 \%$ fish oil microcapsule in diet. Variable measured were feed consumption, egg production, egg weight, mass of egg and feed conversion. Data were analized by CRD and Duncan Multiple Range Test (DMRT). Results of the experiment indicated that the inclusion of fish oil microencapsule in laying quails diet did not affect the production performances (feed consumption, egg production, egg weight, mass of egg and feed conversion).
\end{abstract}

Key words: fish oil microcapsule, performance of laying quail.

\section{PENDAHULUAN}

Puyuh adalah jenis unggas yang dimasukkan dalam aneka ternak. Puyuh sudah sejak lama dikenal masyarakat dan sepuluh tahun terakhir ini telah diusahakan sebagai usaha sampingan maupun usaha peternakan. $\mathrm{Pu}-$ yuh mempunyai potensi yang cukup besar sebagai penghasil telur. Puyuh mampu memproduksi telur mencapai 250-300 butir dalam setahun (Listiyowati dan Roospitasari, 2003). Berat telur puyuh sekitar $8 \%$ dari berat badan induk, hal ini berbeda dengan ayam dimana berat telurnya hanya 3\% dari berat badan induknya. Ternak puyuh telah berkembang pesat di tengah-tengah dominasi ayam ras, walaupun tidak sebesar ayam petelur, namun ternak puyuh menjadi sumber penghidupan masyarakat. Puyuh telah menjadi alternatif bisnis yang menguntungkan, setidaknya sebagai usaha sambilan sekaligus memberi tambahan pendapatan bagi yang mengusahakannya.

Usaha peternakan puyuh sangat tergantung pada pemeliharaan, kebersihan lingku- ngan dan pengendalian penyakit. Dalam pemeliharaan peternakan puyuh, selain makanan dan tata laksana, faktor bibit merupakan hal yang penting untuk mendapatkan performa produksi yang maksimal, puncak produksi dapat mencapai $80 \%$ dari jumlah ternak puyuh. Pemberian pakan pada ternak puyuh yang dilakukan secara tidak terbatas (ad libitum) akan menyebabkan konsumsi pakan berlebih, dan mengakibatkan kelebihan energi yang akan dikonversikan menjadi timbunan lemak dalam tubuh.

Bahan penyusun ransum puyuh umumnya adalah terdiri dari $70 \%$ bahan sumber energi dan $25 \%$ sumber protein. Bahan penyusun ransum puyuh terdiri dari jagung giling, dedak halus, bungkil kedelai, tepung ikan, minyak kelapa, MMI, batu kapur dan topmix. Suplementasi minyak dalam pakan unggas merupakan salah satu cara yang mudah untuk memenuhi kebutuhan energi dan asam lemak esensial ternak. Minyak hewani ikan lemuru, sering digunakan sebagai sumber energi pada pakan unggas, karena mengan- 
dung asam lemak esensial yang sangat dibutuhkan ternak unggas (Wahyu, 1988), di samping itu sebagai sumber asam lemak omega-3.

Umumnya minyak ikan mengandung sekitar 25\% asam lemak jenuh dan $75 \%$ asam lemak tak jenuh. Asam lemak Omega-3 banyak dijumpai pada ikan laut, seperti lemuru, herring, makarel, salmon, tuna, dan anchovy. Minyak ikan lemuru kaya akan EPA yang jumlahnya dapat mencapai 7,1g/100g. Minyak lemuru (Sardinella longiceps) merupakan hasil samping industri pengalengan ikan lemuru yang cukup banyak dan pemanfaatannya belum optimal dan berpotensi sebagai sumber asam lemak omega-3 (Estiasih, 1996).

Pemberian minyak ikan dalam bentuk langsung atau cair ke dalam ransum ternak unggas telah banyak dilakukan. Tujuan pemberian minyak ikan tersebut adalah sebagai sumber energi dalam penyusunan ransum dan juga untuk mendapatkan produk ternak yang tinggi kandungan asam lemak omega-3. Pemberian minyak ikan secara langsung ke dalam ransum membuat ransum menggumpal dan tidak homogen, di samping itu kesulitan dalam penanganan minyak ikan tersebut dalam hal pendistribusian maupun penyimpanan karena minyak ikan tersebut mudah teroksidasi.
Minyak ikan merupakan sumber asam lemak $\omega$-3 rantai panjang dan sangat rentan terhadap oksidasi. Salah satu upaya yang dapat dilakukan adalah pemberian minyak ikan dalam bentuk mikrokapsul minyak ikan. Mikrokapsul minyak ikan diperoleh dengan cara memerangkap minyak ikan dengan bahan penyalut dan selanjutnya dikeringkan dengan pengering semprot, proses tersebut juga dengan mikroenkapsulasi. Sejauh ini pemberian ataupun pengunaan minyak ikan dalam bentuk mikrokapsul ke dalam ransum puyuh belum banyak diungkapkan, oleh sebab itu perlu dilakukan penelitian untuk mengetahui bagaimana pengaruh pemberian mikrokapsul minyak ikan tersebut dalam ransum burung puyuh terhadap performa produksi.

\section{METODE}

Penelitian ini menggunakan ternak puyuh fase layer berumur 5 minggu sebanyak 200 ekor. Ransum disusun dari bahan-bahan seperti jagung, dedak, bungkil kedelai, tepung ikan, minyak kelapa, dan batu kapur. Ransum disusun dengan isoprotein (20\%) dan isokalori (2800 kkal/kg) dan air minum diberikan secara ad libitum komposisi dan kandungan zat-zat makanan dapat dilihat pada Tabel 1 dan Tabel 2.

Tabel 1. Kandungan zat-zat makanan (\%) dan energi metabolisme (kkal/kg) bahan penyusun ransum $^{\mathrm{a}}$

\begin{tabular}{lcccccc}
\hline BahanPakan & PK & Lemak & SK & Ca & P & $\begin{array}{c}\text { ME* } \\
(\text { Kkal/kg) }\end{array}$ \\
\hline Jagung & 7,59 & 2,51 & 1,22 & 0,15 & 0,147 & 3300 \\
Dedak & 13,90 & 4,09 & 13,45 & 0,70 & 0,07 & 1630 \\
Bukil kedelai & 42,46 & 0,88 & 5,67 & 1,08 & 0,343 & 2240 \\
Tepung ikan & 50,14 & 3,42 & 5,69 & 5,59 & 0,62 & $2720^{* *}$ \\
Minyak kelapa & - & 100 & - & - & - & 8600 \\
Topmix & - & - & - & 5,38 & 1,44 & - \\
MMI & 31,50 & 26,62 & 5,48 & 3,89 & 1,23 & 3691 \\
Batu kapur & - & - & - & 35,00 & 5,00 & - \\
\hline
\end{tabular}

\section{Sumber :}

a = Hasil Analisis Laboratorium NNR Fakultas Peternakan Unand

$\mathrm{b}=$ Montesqrit dan Adrizal (2009)

* = ME berdasarkan Scoot et al., (1982)

**= ME berdasarkan Lesson and Summers (2001) 
Tabel 2. Komposisi dan Kandungan Zat-zat Makanan (\%), serta Energi Metabolisme (kkal/kg) Ransum Penelitian

\begin{tabular}{lcccc}
\hline Bahan ransum & \multicolumn{4}{c}{ Ransum Perlakuan $(\%)$} \\
\cline { 2 - 5 } & $\mathrm{A}$ & $\mathrm{B}$ & $\mathrm{C}$ & $\mathrm{D}$ \\
\hline Jagung giling & 57 & 58,5 & 58,5 & 57,5 \\
Dedak halus & 5,5 & 4,8 & 4,8 & 4,8 \\
Bukil kedelai & 12,3 & 11 & 10 & 10 \\
T. Ikan & 20,5 & 20 & 19 & 18 \\
Minyak kelapa & 1 & 0 & 0 & 0 \\
MMI & 0 & 2 & 4 & 6 \\
Batu kapur & 3,5 & 3,5 & 3,5 & 3,5 \\
Topmix & 0,2 & 0,2 & 0,2 & 0,2 \\
\hline Total & 100 & 100 & 100 & 100 \\
\hline PK $(\%)$ & 20,59 & 20,44 & 20,18 & 3,23 \\
Lemak (\%) & 3,46 & 3,18 & 3,47 & 3,29 \\
SK (\%) & 3,29 & 3,23 & 3,26 & 2,70 \\
Ca (\%) & 2,64 & 2,67 & 2,68 & 0,49 \\
P (\%) & 0,44 & 0,45 & 0,47 & 2910,80 \\
ME (Kkal/kg) & 2889,77 & 2872,96 & 2897,18 & \\
\hline
\end{tabular}

Keterangan :Dihitung berdasarkan Tabel 1.

MMI= Mikrokapsul Minyak Ikan

Mikrokapsul minyak ikan diperoleh dengan cara memerangkap minyak ikan dengan bahan penyalut berupa : tepung daging dan tulang serta bungkil kelapa kemudian dikeringkan dengan pengering semprot (Montesqrit dan Adrizal, 2009).

Penelitian dilakukan secara eksperimen dengan rancangan percobaan Rancangan Acak Lengkap (RAL) menggunakan 4 perlakuan dan 5 ulangan. Setiap unit terdiri dari 10 ekor puyuh sebagai unit percobaan. Perlakuan adalah penggunaan mikrokapsul minyak ikan dalam ransum.

Perlakuan tersebut adalah: RA = Ransum memakai $0 \%$ mikrokapsul minyak ikan; RB = Ransum memakai 2\% mikrokapsul minyak ikan; $\mathrm{RC}=$ Ransum memakai $4 \%$ mikrokapsul minyak ikan; RD = Ransum memakai 6\% mikrokapsul minyak ikan. Jika ada perbedaan antar perlakuan diuji dengan Duncan Multiple Range Test (DMRT) (Steel and Torrie, 1980).

Peubah yang diamati dalam penelitian ini adalah: 1) Konsumsi ransum (gram/ekor/ hari) diukur dengan pemberian ransum yang ditimbang setiap hari kemudian dikurangi sisa ransum; 2). Produksi telur telur harian (Quail day)(\%) dihitung dengan membagi jumlah telur pada hari yang bersangkutan dengan jumlah puyuh yang hidup pada hari yang sama dikali 100\%; 3). Berat telur (gram/butir) diperoleh dengan menimbang telur setiap harinya dan dirata-ratakan sampai selesai penelitian; 4) Massa telur (gram/ekor/hari) dihitung dengan persentase produksi telur harian (Quail day) selama satu bulan dikalikan dengan berat telur rata-rata (gram/butir/hari) yang dihasilkan dalam bulan tersebut; dan 5) Konversi ransum dihitung dengan membandingkan jumlah makanan yang dikonsumsi dengan produksi (massa telur) selama penelitian.

\section{HASIL DAN PEMBAHASAN}

Pengaruh pemberian mikrokapsul minyak ikan (MMI) dalam ransum puyuh terhadap konsumsi ransum, produksi telur, massa telur dan konversi ransum dapat dilihat pada Tabel 3.

\section{Konsumsi Ransum}

Konsumsi ransum puyuh selama penelitian berkisar dari 20,17 gram/hari sampai 20,75 gram/hari. Hasil analisis ragam menunjukkan bahwa pemberian mikrokapsul minyak ikan (MMI) sampai taraf 6\% memberikan pengaruh yang berbeda tidak nyata 
$(\mathrm{P}>0,05)$ terhadap konsumsi ransum puyuh petelur (Tabel 3). Hal ini disebabkan pemberian mikrokapsul minyak ikan (MMI) sampai taraf $6 \%$ dalam ransum tidak mempengaruhi palatabilitas ransum, sehingga konsumsi ransum tidak berbeda dengan ransum kontrol, hal ini disebabkan karena dengan proses mikroenkapsulasi dapat mengurangi bau amis sehingga tidak mempengaruhi palatabilitas dan juga karena ada tambahan bahan penyalut berupa tepung daging dan bungkil kelapa yang dapat meningkatkan palatabilitas.

Hal lain yang menyebabkan konsumsi ransum tidak berbeda karena mikrokapsul minyak ikan yang ditambahkan stabil dan tidak tengik, sebab jika lemak atau minyak yang ditambahkan tengik akan menyebabkan palatabilitas ransum menurun sehingga konsumsi rannsum menurun. Anggorodi (1995) menyatakan salah satu faktor yang mempengaruhi konsumsi ransum adalah palatabilitas ransum. Pemberian mikrokapsul minyakikan pada ransum puyuh belumbanyak dilakukan. Oleh sebab itu perlu dibandingkan dengan penelitian pada puyuh dengan pemberian minyak ikan. Hasil penelitian Saerang (2003) menyatakan bahwa penggunaan minyak ikan lemuru dalam ransum puyuh tidak mempengaruhi konsumsi ransum bila dibandingkan dengan ransum kontrol. Sedangkan Suripta dan Astuti (2006) menyatakan bahwa penambahan minyak ikan dalam ransum puyuh sampai $4 \%$ menurunkan konsumsi ransum bila dibandingkan dengan kontrol.

Rataan konsumsi ransum yang diperoleh pada penelitian masih dalam batas konsumsi standar. Djulardi (1995) menyatakan konsum- si ransum puyuh pada umur 42 hari sampai afkir sebesar $21 \mathrm{gr} / \mathrm{ekor} / \mathrm{hari}$.

\section{Produksi Telur}

Rataan produksi telur selama penelitian berkisar dari 52,23 sampai 55,79\%. Hasil analisis ragam menunjukkan bahwa pemberian mikrokapsul minyak ikan sampai taraf $6 \%$ tidak memberikan pengaruh yang nyata terhadap produksi telur puyuh (Tabel 3). Hal ini disebabkan oleh kecukupan kandungan nutrisi antar perlakuan yang menyebabkan puyuh dapat berproduksi dengan baik, sehingga tidak mempengaruhi proses pembentukan telur dan produksi telur dapat berjalan dengan normal. Hal lain yang menyebabkan tidak terpengaruhnya produksi telur karena ransum yang digunakan antar perlakuan disusun secara isokalori dan isoprotein yang membedakannya hanya kadar lemak kasar.

Tidak terpengaruhnya produksi telur akibat penambahan minyak ikan lemuru dalam ransum puyuh didukung oleh penelitian Zufrizal (2001); Saerang (2003); dan Suripta dan Astuti (2006). Produksi telur yang diperoleh dalam penelitian tidak jauh berbeda dengan yang didapatkan peneliti lain. Suripta dan Astuti (2006) pemberian minyak ikan dalam ransum puyuh menghasilkan produksi telur sebesar 54,89\% dengan lama pemeliharaan selama 12 minggu.

\section{Berat Telur}

Rataan berat telur puyuh selama penelitian berkisar 8,26 sampai 8,47 gram. Hasil analisis ragam menunjukkan bahwa pemberian mikrokapsul minyak ikan sampai taraf

Tabel 3. Rataan performa produksi puyuh

\begin{tabular}{lccccc}
\hline & \multicolumn{5}{c}{ Performa Produksi } \\
\cline { 2 - 6 } Perlakuan Ransum & $\begin{array}{c}\text { konsumsi } \\
\text { ransum } \\
\text { (gr/ekor/hari) }\end{array}$ & $\begin{array}{c}\text { Produksi } \\
\text { telur } \\
(\%)\end{array}$ & $\begin{array}{c}\text { Berat telur } \\
\text { (gr/butir) }\end{array}$ & $\begin{array}{c}\text { Massa telur } \\
\text { (gr/hari) }\end{array}$ & $\begin{array}{c}\text { Konversi } \\
\text { Ransum }\end{array}$ \\
\hline A (0\% MMI) & $20,75 \pm 0,78$ & $55,79 \pm 5,07$ & $8,31 \pm 0,24$ & $4,63 \pm 0,34$ & $4,49 \pm 0,28$ \\
B (2\% MMI) & $20,61 \pm 1,13$ & $52,23 \pm 2,03$ & $8,47 \pm 0,13$ & $4,42 \pm 0,18$ & $4,73 \pm 0,73$ \\
C (4\% MMI) & $20,63 \pm 1,15$ & $55,11 \pm 4,51$ & $8,28 \pm 0,20$ & $4,57 \pm 0,51$ & $4,62 \pm 0,54$ \\
D (6\% MMI) & $20,17 \pm 0,51$ & $55,39 \pm 3,11$ & $8,26 \pm 0,17$ & $4,67 \pm 0,23$ & $4,74 \pm 0,64$ \\
\hline
\end{tabular}

Ket: analisis Ragam menunjukkan tidak berbeda nyata $(\mathrm{P}>0,05)$ 
$6 \%$ dalam ransum puyuh memberikan pengaruh yang tidak nyata terhadap berat telur (Tabel 3). Hal ini disebabkan adanya keseimbangan zat makanan dalam ransum masingmasing perlakuan sehingga perlakuan ransum tidak mempengaruhi berat telur. Hal lain yang menyebabkan tidak terpengaruhnya berat telur akibat pemberian mikrokapsul minyak ikan (MMI) dalam ransum adalah karena penambahan mikrokapsul tersebut tidak mempengaruhi proses pembentukan telur akan tetapi mempengaruhi komposisi kandungan lemak dalam kuning telur.

Penelitian sebelumnya yang menggunakan minyak ikan lemuru dalam ransum puyuh tidak nyata mempengaruhi berat telur (Zuprisal dkk, 2001; Suripta dan Astuti, 2006). Rataan berat telur pada penelitian ini berkisar 8,26-8,47 gr/butir. Hasil ini tidak jauh berbeda dengan penelitian Suripta dan Astuti (2006) berat telur puyuh sampai umur 12 minggu adalah 8,93 gr/butir. Rendahnya berat telur pada penelitian ini diduga disebabkan karena puyuh belum mencapai puncak produksi. Nugroho dan Mayun (1986) menyatakan bahwa telur puyuh saat permulaan bertelur berukuran kecil, ukuran telur membesar sesuai pertambahan umur sampai mencapai besar yang stabil.

\section{Massa Telur}

Rataan massa telur selama penelitian berkisar 4,42-4,67 gr/butir/hari. Hasil analisis ragam menunjukkan bahwa pemberian mikrokapsul minyak ikan (MMI) sampai taraf 6\% memberikan pengaruh yang berbeda tidak nyata $(\mathrm{P}>0,05)$ terhadap massa telur puyuh petelur. Hal ini disebabkan oleh produksi telur, berat telur dan konsumsi ransum juga tidak dipengaruhi oleh pemberian mikrokapsul minyak ikan (MMI). Persentase produksi telur dan berat telur mempengaruhi produksi massa telur, sedangkan produksi massa telur dan konsumsi ransum mempengaruhi konversi ransum. Hasil penelitian ini tidak jauh berbeda dengan hasil penelitian Muslim (2010) di mana massa telur puyuh sampai 8 minggu produksi adalah 4,39 g/ekor/hari.

\section{Konversi Ransum}

Rataan konversi ransum selama penelitian berkisar 4,49 - 4,74. Hasil analisis ragam menunjukkan bahwa pemberian mikrokapsul minyak ikan (MMI) sampai taraf 6\% dalam ransum puyuh tidak nyata meningkatkan konversi ransum (Tabel 3). Hal ini disebabkan oleh massa telur dan konsumsi ransum juga tidak dipengaruhi oleh pemberian mikrokapsul minyak ikan (MMI). Menurut Muslim (2010) konversi ransumpuyuh sebesar 4,96 selama 8 minggu penelitian. Zuprizal dkk. (2001) menyatakan bahwa pemberian minyak ikan lemuru pada ransum puyuh sampai taraf $8 \%$ tidak mempengaruhi konversi ransum. Menurut Suripta dan Astuti (2006) konversi ransum pada puyuh yang diberi minyak ikan lemuru adalah 3,19 dan Rospitasari (1995) menyatakan bahwa konversi ransum puyuh umur 16 minggu adalah 2,63-3,83. Tingginya konversi ransum pada penelitian ini disebabkan puyuh belum mencapai puncak produksi dan puyuh baru berumur 13 minggu.

\section{KESIMPULAN}

Berdasarkan hasil penelitian ini dapat disimpulkan bahwa penggunaan mikrokapsul minyak ikan dalam ransum puyuh sampai taraf $6 \%$ tidak mempengaruhi performa produksi.

\section{DAFTAR PUSTAKA}

Anggorodi, H, R.1995. Ilmu Makanan Ternak Umum. PT. Gramedia, Pustaka Utama, Jakarta.

Djulardi, A., Muis. H dan Latif. S. A. 2006. Ilmu Nutrisi Aneka Ternak dan Satwa Harapan. Andalas University Press. Padang.

Estiasih, T. 1996. Mikroenkapsulasi Konsentrat Asam Lemak Omega-3 dari Limbah Cair Pengalengan Ikan Lemuru (Sardinella longiceps). 
Program Pasca Sarjana, Universitas Gadjah Mada, Yogyakarta.

Leeson, S., and J. D. Summer. 2001. Nutrition of The Chicken, Fourth Ed. Departement University of Guelph Ontario, Canada.

Listiyowati, E dan K. Roospitasari. 2003. Puyuh: Tatalaksana Secara Komersial. Cetakan ke 13. Penebar Swadaya. Jakarta.

Montesqrit dan Adrizal. 2009. Optimasi Produksi Mikrokapsul Minyak Ikan Sebagai Feed Aditif untuk Menghasilkan Produk Unggas Kaya Asam Lemak $\omega$-3 dan Kolesterol Kuning Telur. Laporan Penelitian Hibah Bersaing.Universitas Andalas. Padang.

Muslim. 2010. Pemberian campuran dedak dan ampas tahu fermentasi Monascus purpureus terhadap performa dan kualitas telur burung puyuh. Tesis. Program Pasca Sarjana Universitas Andalas, Padang.

NRC. 1997. Nutrient Requirement of Poultry. $7^{\text {th }}$ Ed. National Academy of Science. Washington DC.

Nugroho, dan I.G.K.Mayun. 1986. Beternak Burung Puyuh. Penerbit Eka Offset. Semarang.

Saerang, J.L.P. 2003. Efek pakan dengan penambahan berbagai minyak terhadap produksi dan kualitas telur. Program Pascasarjana IPB. Bogor.

Scott, M. L.,M.C. Nesheim and R.J. Young. 1982. Nutrition of The Chicken Fourth Ed. Published by M. L. Scott and Associates, Ithaca, New York.

Wahyu, J. 1988. Cara Pemberian dan Penyusunan Ransum Unggas. Cetakan ke-4. Fakultas Peternakan. Institut Pertanian Bogor. Bogor.

Zuprizal, Cuk Tri Noviandi, Indratiningsih dan Sri Harimurti. 2002. Studi transfer omega-3 yang berasal dari limbah industri pengolahan ikan terhadap komposisi kimia telur berbagai jenis unggas. Karya Ilmiah Hasil Penelitian. Lembaga Penelitian UGM. Yogyakarta 